\title{
A Glance at the Mozambican Dairy Research
}

\section{Edgar Cambaza}

Laboratory of Food Process Engineering, Graduate School of Agriculture, Hokkaido University, Sapporo, Hokkaido, 060-0808 Japan

Department of Biological Sciences, Faculty of Sciences, Eduardo Mondlane University, Av. Julius Nyerere, nr. 3453 Maputo, Mozambique

Correspondence: edy@bpe.agr.hokudai.ac.jp; Tel.: +81-80-2876-1106

\begin{abstract}
The Mozambican dairy industry landscape is not well known because the research about it presents numerous inconsistencies. These inconsistencies are possibly due to miscommunication between scholars, entrepreneurs, the government and other actors, besides major events such as the civil war and policy changes and overall lack of coordination. This study aimed to catalog and relate the major studies and findings in the Mozambican dairy research, contextualize them historically, analyze the implications and provide hints for future researchers. Dairy research seemed intimately related to the industry's development, and it has been dependent on the country's sociopolitical changes and opportunities. Social and economic studies are more abundant, perhaps because the dairy industry is emerging, thriving to stand out in a very competitive environment, but there are also studies in applied sciences, especially microbiology and chemistry. There are promising directions to follow such as the improvement of herding techniques (e.g. feeding, disease control), multidisciplinary synergies or exploration of traditional dairy products such as masse. Also, it would be important for institutions to share their research through electronic platforms, even the information published prior to the existence of the worldwide web.
\end{abstract}

Keywords: Mozambique; dairy; research

\section{Introduction}

It seems even arguable if there is a dairy industry or not in Mozambique. On one side, Zvomuya [1] described this sector as "virtually non-existent" and some authors agreed through a chain of cross-references [2,3], while on the other hand Castel-Branco [4] classified it as an "emerging agricultural industry". Whatever the point of view is, there are several smallholder dairy farms, at least 8 milk-processing companies [1,3,5] throughout the country, several markets selling the domestic milk [1,6] and perspectives to export dairy products [1]. Thus, there is a value chain on which several people depend and it deserves some attention. Furthermore, there seems to be an increasing interest in the matter.

Alberro [7] called for the need to produce more animal protein in tropical developing countries almost 40 years ago but even now it has been difficult in Mozambique because the most productive cows are not well adapted to tropical settings. Quisumbing, et al. [2] agreed and added that a 16-year post-independence civil war also prevented the dairy industry to develop. Thus, it is necessary to study how the milk production could be improved. The country has very little research about dairy manufacturing and its industry $[1,6]$. A challenged body of multidisciplinary academic work have been accompanying the thriving dairy sector, describing its status or seeking for solutions and improvements [6,8].

There were some bursts of considerable research but they do not seem to be planned as long-term projects. As result, the current knowledge is fragmented in contextualized pieces from certain places and periods, sometimes inconsistent or even conflicting [3,8]. Future researchers will need a concise catalog showing how each study on the Mozambican dairy manufacturing is located 
within the zeitgeist considering the country's historical, social, economic and scientific intricacies. This article aims to provide a comprehensive view of the current dairy research in Mozambique, trying to explain how it took its shape, its impact on the current state of knowledge, and which directions could be taken in the near future.

The article will start by presenting the country's geographic features because there are several references to cities and provinces, and also to sociopolitical issues. Then, it will describe how the dairy industry evolved throughout the country's history, and finally describe how the research has been carried and how it contributed to the present knowledge on the Mozambican dairy manufacturing.

\section{Geographic Features}

The Republic of Mozambique (Figure 1) is a South-eastern African country bordering Mozambique Channel with a coastline of $2,470 \mathrm{~km}[9,10]$. The geographic coordinates are $18^{\prime} 15^{\prime \prime} \mathrm{S}$ and 35' 00" E [9]. The country is surrounded by Tanzania (north), Malawi and Zambia (northwest), Zimbabwe (west), Swaziland (south) and South Africa (southeast) [10]. The total area is $799,380 \mathrm{~km}^{2}$, being $786,380 \mathrm{~km}^{2}$ of land and $13,000 \mathrm{~km}^{2}$ of water [9]. The climate is tropical and subtropical humid $[9,10]$ and it has fertile soils, especially in the northern mountainous areas near the Zambezi river [11].

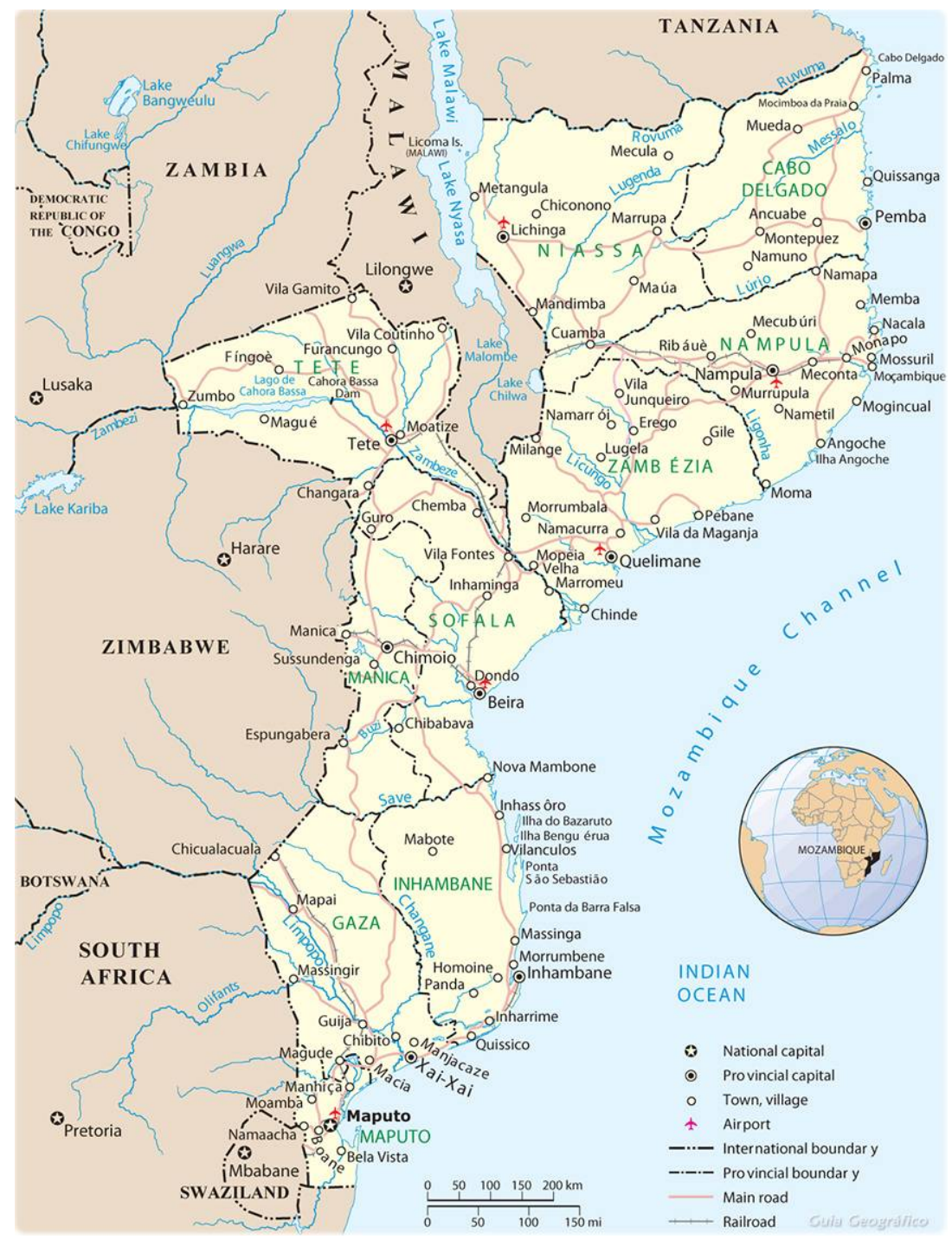


The total population is estimated to 23.9 million people [13]. According to United Nations Children's Fund (UNICEF) [14] and [15], about 69\% live in rural areas. Though it had one of the African highest annual economic growth rates (6.8-7.6\%) in the last decade, Mozambique but a civil war (1977-1992), natural calamities among other issues are the reasons why the country still depends on $40 \%$ of foreign assistance for its annual budget $[9,13,16]$. The GDP is 12.9 billion US dollars and it comes from agriculture $(29.8 \%)$, industry $(23 \%)$ and services $(47 \%)[13,18]$. The main exports are cashew products (US\$ 21 million), prawn (US\$ 42 million) and manufactures (US\$ 34 million) $[13,18]$ but there are other commodities such as aluminium, electricity, tobacco, sugar, cotton and timber $[18,19]$.

The main export partners are Netherlands (36.9\%), South Africa (14.6\%), Portugal (3.4\%) and China (2.5\%) [18]. The local cashew industry used to be the World leader, with $35-40 \%$ international market share but it had a downsizing basically because of inefficiencies during a major economic reform [20,21]. Yet, Große-Rüschkamp and Seelige [22] reported a growth from 0.5 to 3.25 million tonnes from middle 1980s to 2007.

\section{Historical context}

It is necessary to have an idea about the evolution of the Mozambican sociopolitical context in order to better visualize the research directions in the dairy industry. The country has undergone several changes since the colonial era, independence, civil war, establishment of a democratic system and harmonization with the Millennium Declaration [23,24]. These changes led to economic readjustments and certainly affected all sectors of production, including research and development.

The Portuguese effectively occupied Mozambique soon after the Berlin Conference (1884-85) and the defeat of the Emperor Ngungunhane (1895). Since then, they controlled the production. According to Raikes [25], the dairy industry grew considerably just before the independence (1950-65) because the major cities were growing and attracting people from the metropolis, demanding "high-income foodstuffs" such as wheat flour, meat and dairy. A network of supply chains developed rapidly, enhanced by the participation of South African farmers and firms. However, the war of independence (1964-74) and its aftermath certainly destabilized the sector.

The post-colonial Government (1975-89) discouraged the private sector because the country was under a Marxist-Leninist orientation with one party, and all major decisions were under central rule. Even education and research should comply with the country's priorities, with little flexibility to develop. For instance, the Government ceased some departments of the only university at that time (Eduardo Mondlane). This setting certainly discouraged research in any field and international collaborations, especially from countries under a different regime.

In 1987, Mozambique changed its priorities to get support from the International Monetary Fund (IMF) and the regime changed to democratic. The resulting project was designated Economic Rehabilitation Program, under which the Government allowed citizens to purchase most of its properties and stimulated entrepreneurship [26,27]. According to Vernooij, et al. [3], most dairy farms were privatized between 1994 and 1997. The state also developed strategies to attract foreign investment and collaborations such as transference of technology, capacity building and assistance. The academia also expanded, private schools and research centers opened, providing means for some research to take place. The situation became even more favorable after the peace treaty, signed on October $4^{\text {th }}$, 1992. Yet, there is very little information on the Mozambican dairy industry during 1990s. Perhaps the most relevant is the overview by Faftine [28] on the use of cows in smallholder farming systems presented in Ethiopia, 1995. This shortage of information is possibly because: the governance was under transition, drawing most attention to production instead of research; priority areas were fisheries and cash crops such as cassava, maize and peanuts; there was no investment for the dairy industry; there was little technical or academic expertise and technology related to dairy production; the new open market promoted competition, and assessments were made between institutions under professional secrecy.

The new millennium came with a new worldwide sociopolitical framework, partially because of the Millennium Development Goals (MDG), and now the Sustainable Development Goals (SDG) 
118 [24]. As response, Mozambique developed the Plan of Activities to Reduce Poverty (PARP) [29], 119 facilitating the introduction or expansion of projects able to address the goals, especially the combat 120 against poverty, hunger and disease. There were also strong incentives for education. A real locally 121 based dairy industry started to take shape in this era: South African branch of Parmalat SpA opened 122 a facility in Maputo Province [30], Brendon Evans inaugurated Gouda Gold in Manica province [1], 123 Land $\mathrm{O}^{\prime}$ Lakes start collaborating with dairy farm smallholders [6] and several dairy plants took off 124 throughout the country [3]. Some research accompanied the establishment of such firms, most related to economic viability. Furthermore, dairy research is likely to become more active in Mozambique because there is an increasing number of research centers, universities and polytechnic institutes with food science programs [31].

\section{8}

129

130

131

132

133

134

135

136

137

138

139

140

141

142

143

144

145

146

147

148

149

150

151

152

153

154

155

156

157

158

159

160

161

162

163

164

165

166

167

\section{Early Studies}

There was an extensive research on the Mozambican dairy production during the colonial era. Pereira Martinho [32] presented the results in his book called Some Aspects of the Livestock Problem in Mozambique, with details such as the cow types, their productivity and distribution throughout the territory, owners' ethnicities and how they treated the cows. According to him, cows were less abundant in Mozambique compared to the surrounding territories, most farms were located at the southern area, and the native cows were not as productive as Friesians. Achá, et al. [33] say this is due to abundance of tse-tse fies (Glossina spp.). Landim, the preferred local type, was crossed with European breeds, originating considerably productive cows. For instance, Landim $x$ Friesian was able to produce 3000 liters in 300 days in the $4^{\text {th }}$ or $5^{\text {th }}$ lactation, and Landim $\times$ Jersey could produce 2000 liters for a similar period.

Some post-colonial studies are available in David Lubin Memorial Library of the Food and Health Organization of the United Nations [34]. They covered different aspects of dairy production and how to improve it. The readily accessible literature has very little information on how these studies were conducted and even their results. But it is possible to grasp the state of research and where it was heading.

Alberro [7] kick-started the post-colonial research in 1980 by comparing the productivity between Holstein, Dutch and Africander x Friesian heifers. The two former started producing milk earlier, and yielded more for a longer period than Africander. The following year he described the management, feeding and behavior of Friesian dairy herds in the coastal belt of Mozambique [35]. In 1984, a group of scientists presented studies on reproduction of Mozambican dairy cattle in the 10th International Congress on Animal Reproduction and Artificial Insemination, Illinois, United States. Diaz talked about abortion and death [36], Rocha and Diaz about artificial insemination [37], and Thompson about microbial flora in the cervical mucus of dairy cows. The same year, Raikes [25] mentioned dairy production in his article on how policies are affecting the food industry in Mozambique.

Another important study was published by Alinder and Ingevall [38] in 1985. After a soil survey in the country's southern region, they conceived an irrigation scheme for a dairy farm. The same year Maputo City hosted the Seminar on Animal Production, where de Vries [39] and Diaz [40] presented their progress on dairy research. The former proposed the introduction of rice straw in dairy cattle's diet and the latter suggested some improvements for the dairy cattle production in Mozambique.

The studies mentioned in this section were focused on the cattle's health rather than dairy quality or safety. This was possibly because the country was still attempting to re-establish the industry after the Portuguese left with key manufacturing resources. Dairy production relied on large farms with exotic animals, modern equipment, special feedstuffs, drugs, and a timely arrival of supplies and services [25]. Furthermore, the country was struggling to implement post-colonial policies and under a civil war from 1977 to 1992 [2,41,42]. 
168

170

171

172

173

174

175

176

177

178

179

180

181

\section{Recent Studies}

Among recent documents worth mentioning about dairy production in Mozambique, the ones on Table 1 are enough to cover the most relevant information. Other studies are either related or do not seem as pertinent. They will be mentioned when or if necessary. The major documents on dairy food in Mozambique are mostly journal articles but there are also magazine feature articles, proceedings, and academic dissertations, project reports, among others. Most cover agribusiness, economics or social sciences but few also feature natural sciences or multidisciplinary studies. The frequent focus on farm management is perhaps due to the recent strong incentive to entrepreneurship in Mozambique, especially for agriculture [43,44]. Former President Armando Guebuza introduced a fund to develop small and medium-sized enterprises in the countryside to stimulate development and decentralize the economy [45], accessible for any citizen who presented a mid-long term sustainable plan [46,47]. The following discussion will first focus on economics and the social studies, and then natural sciences.

Table 1. Major recent publications describing dairy production in Mozambique.

\begin{tabular}{ccccc}
\hline Year & Author & Document type & Subject & Focus \\
\hline 1995 & Faftine [28] & Proceeding & Economics & Farm management \\
\hline 2003 & Castel-Branco [4] & Journal article & Economics & Industry analysis \\
\hline 2004 & Achá, et al. [33] & Journal article & Microbiology & Animal health \\
\hline 2008 & Slabbert [30] & Magazine article & Agribusiness & Interview (entrepreneur) \\
\hline 2009 & Zvomuya [1] & Magazine article & Agribusiness & Interview (entrepreneur) \\
\hline 2011 & Rungo [48] & Dissertation & Chemistry & Milk quality \\
\hline 2012 & Zucula [49] & Dissertation & Chemistry & Milk quality \\
\hline 2013 & Schutte [50] & Dissertation & Microbiology & Milk quality \\
\hline 2014 & dos Anjos, et al. [51] & Journal article & Animal production & Cassava as cow feed \\
\hline \multirow{2}{*}{2015} & Ouana [52] & Dissertation & Chemistry & Butter quality \\
\cline { 2 - 5 } & Johnson, et al. [53] & Journal article & Gender studies & Farm management \\
\cline { 2 - 5 } 2016 Chagunda, et al. [54] & Journal article & Agribusiness & Farm management \\
\cline { 2 - 5 } & $\begin{array}{c}\text { Vernooij, } \text { et al. [3] } \\
2018\end{array}$ & $\begin{array}{c}\text { Consultancy } \\
\text { report }\end{array}$ & Agribusiness & Industry analysis \\
\hline
\end{tabular}

\subsection{Economic and social studies}

Dr. Olga Faftine [28] can be considered the first scholarly authority describing the dairy industry after the peace treaty (1992) and establishment of the first democratic Government (1994). In summary, she confirmed the predominance of cattle in the country's south and center and provided a glance on the changes during the civil war. According to her, the number of cows declined from one million to around 200,000 in 1992 and milk production from 10 million to 1 million liters per year. However, it is reasonable not to consider Faftine's analysis as part as the most recent dairy research because he published his document when the Government was following the Program for Economic Rehabilitation rather than the current Plan for Poverty Reduction. Furthermore, the flood in 2000 affected several farmers throughout the country's south and center [55], many lost their goods and had to be reallocated, affecting the area's agricultural landscape. Yet, the country kept most agricultural policies and several aspects he mentioned still apply [1] or can facilitate the understanding of the current situation.

The United Nations (UN) [56] has records on the number of dairy cattle and milk production in Mozambique since 1991 (Figure 2). According to the database, the number of dairy cows seems to 
have increased from perhaps lower than 300,000 head to almost 600,000, and there were two leaps of a considerable proliferation: 2008 and 2014. Raimundo Diomba, Manica provincial governor, also stated this trend when he said that milk market was expanding as response to consumer demand [1]. However, UN's values seem too high for the values reported by Faftine [28] and Vernooij, et al. [3] and low for Zvomuya's [1]. For instance, Vernooij, et al. [3] said the annual milk production is 82,000 metric tones annually, according to the Emerging Markets Analysts Report published in 2014, but the author recognizes that "exact figures on milk production in Mozambique are scarce and often conflicting". The differences are possibly because information technologies have been improving and facilitating services such as census and statistics, and UN regularly updates its database. Furthermore, part of the milk produced locally is sold informally [3], and part of it is pottentially underreported.

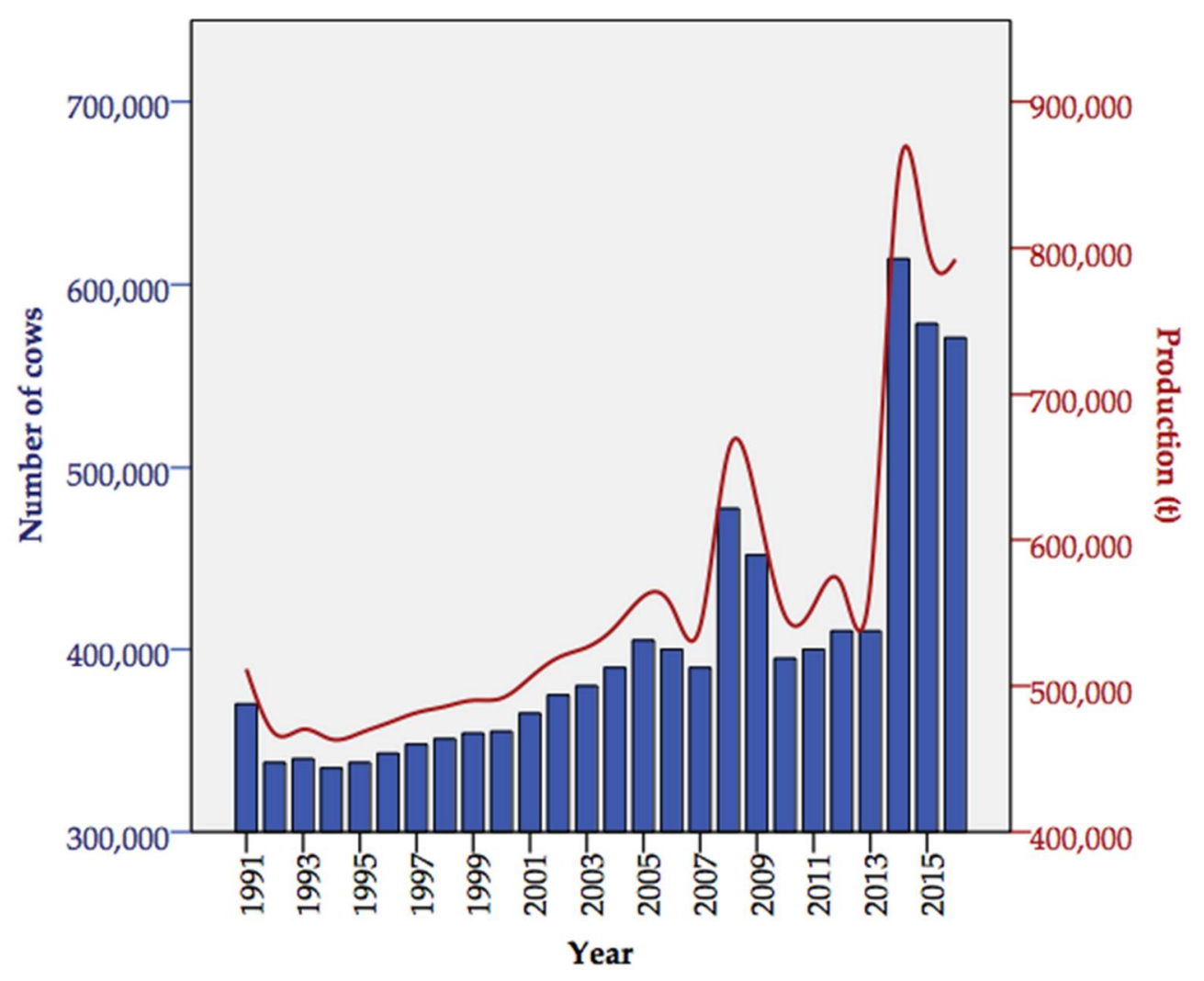

Figure 2. Number of cattle and milk production in Mozambique from 1991 to 2016. The bars represent the number of head and the red line represents the variation in the quantity of milk. Note: $\mathrm{t}$ - metric tones. Based on UN [56].

Milk production showed a very similar trend to the number of head, increasing from around 500,000 to 800,000 tonnes. It suggests that yield did not change considerably. Indeed, a Kolmogorov-Smirnov one-sample test of the yield provided by UN [56] showed not significant variation over time $(p=0.96)$, with the confidence interval $13846-59$ hectoliters per cow annually. In this case, both Faftine [28] and Zvomuya's [1] presented "humbler" statistics, with values below 80,000 tonnes. The quantity of milk produced in Mozambique seems reasonable if compared to other african countries. For instance, while Kenya and Ethiopia show records of over a million tonnes, Madagascar, Uganda and Tanzania present values close to Mozambique's [57]. Yet, Zvomuya's [1] said milk consumption is very low even for the quantity produced. According to the author, the average Mozambican consumea only 5.7 liters of milk annually, and it declined from 9.1 liter in 1990. For the sake of comparison, he said the world average is 79 liters per capita.

Ten years later, Castel-Branco [4] published the following relevant article considering that Faftine actually described facts up to 1992. He wrote about Mozambican economic growth in 
general, mentioning the dairy production in few instances as example. He classified dairy manufacturing as an emerging agricultural industry because it heavily relies on imported products in late stages of processing. Indeed, two interviews published in the Dairy Mail Africa subsidize Castel-Branco's line of though. Slabbert [30] interviewed Parmalat's chief executive officer (Theo Hendrickse), and identified this company as the leading dairy factory in Mozambique. The author said said that the country's branch has been considerably profitable, even when Parmalat was facing a crisis worldwide. But Zvomuya [1] said the company does not produce or refine raw milk, instead Parmalat imports all inputs including packaging material and powdered milk and sells as ultra-high-temperature (UHT) processed milk. Mahomed and Nunes [6] identified Gouda Gold and Land $\mathrm{O}^{\prime}$ Lakes as the largest dairy manufacturers relying solely on local raw material and delivering finished products. Table 2 shows these and other major dairy producers in Mozambique.

Table 2. The major dairy manufacturers in Mozambique and their product features.

\begin{tabular}{cccc}
\hline Province & Company name & Dairy input & Main products \\
\hline \multirow{2}{*}{ Maputo } & Parmalat & $\begin{array}{c}\text { Imported } \\
\text { Imported }\end{array}$ & $\begin{array}{c}\text { Fresh milk, cheese } \\
\text { Condensed milk, cheese }\end{array}$ \\
\hline Pofala & Copolate & Local & Fresh milk \\
\hline \multirow{4}{*}{ Manica } & DanMoz & Local & Fresh milk \\
& AgroMaco & Local & Fresh milk \\
& Gouda Gold & Local & Fresh milk, cheese \\
& Land O' Lakes & Local & Fresh milk \\
\hline Nampula & Rafza Rostongy & Local & Fresh milk \\
\hline Adapted from Vernooij, et al. [3], Mahomed and Nunes [6], and Zvomuya [1].
\end{tabular}

The processing plants from Maputo import their material, partially processed, focusing their activity more on the final steps, packaging and branding [1,58]. Assuming that cattle farms are more abundant in the country's south and center $[28,33]$, it would be reasonable to expect the companies of Maputo to use local raw materials, as it is the Mozambique's most southern province. However, the area is strategically located near South Africa, the Maputo-Witbank road facilitates circulation between both countries [59], South Africa has relatively low cost high quality milk [60], more stable and predictable price fluctuations [61,62], and the local supply might not be enough for demands of Parmalat and Protal. Furthermore, historical reasons should be also considered. Parmalat was introduced in Maputo through the South African subsidiary $[1,30]$ and it certainly had already an established supply chain, entering Mozambique especially to sell the milk and derivatives. Protal also commenced as an import-export firm for condensed milk and processed cheese [58].

Fidelis Zvomuya [1] interviewed the founder of Gouda Gold, Brendon Evans, providing valuable insights about the Mozambican dairy industry in 2009. The entrepreneur described the industry as "virtually non-existing" until he went to Mozambique as a refugee from Zimbabwe's regime in 2002, and established in Manica Province with only 20 cows from the originally over 200. His radical view perhaps refers to the absence of coordinated enterprises covering the entire dairy production chain consistently responding to market's demands. Evans was pioneer in this sense by opening the first cheese-manufacturing factory in Mozambique, inaugurated in May 2007 and built to meet international and European Union standards, so as the Guidelines of the International Labor Organization (ILO). The company has Dutch partners such as Scherjon Dairy Equipment and Advance Consulting Haarl, and the Private Sector Investment Program (PSI), formerly known as PSOM. These organizations provided assistance, equipment and loans to support Gouda Gold.

Land O' Lakes managed an initiative called Manica Smallholder Dairy Development Program (MSDDP) from 2008 to 2012 to rebuild the Mozambican dairy industry and increase smallholder farmers' income as milk producers. The cooperative claims to have doubled the number of dairy cows and tripled the volume of milk produced in Manica [63]. The company has plenty of information on the program at its website [64] but there also are some scholarly documents on the topic. For instance, Nancy Johnson et al. published two papers [2,53], both focused on the female 
contribution for the success of the initiative. According to them and Zvomuya [1], the United States Department of Agriculture awarded Land O' Lakes a Food for Progress Project grant to support dairy farmers from Manica Province. The company used USD \$6 million to provide 400 dairy cows to local farmers and to finance artificial insemination. After a survey in 125 households in 2011 and 150 in 2012, Johnson et al. [53] found that: men owned most assets such as lands and cows but they frequently shared with their wives, still keeping the control over the revenues; the participation in the program increased the farmers' income and access to nutritious food, regardless if the assets were managed by men or women; men tended to reinvest the revenue in assets to improve the business while women spent most of it improving the household quality of life. In any case, dairy business seemed to increase farmers' income and promote the participation of women in the labor force, thus empowering them.

In 2016, Chagunda, et al. [54] published another study related with MSDDP, though this was about the initiative in Mozambique and four other countries from Subsaharan Africa: Kenya, Tanzania, Malawi and Zambia. They shared valuable insights about Mozambique. For instance, they described the average land size per smallholder ( $3.88 \mathrm{ha}$ ), the use cassava roots and leaves to feed cattle, and the cross-breeding between the ingenous zebu cattle and Holstein-Friesian.

Vernooij, et al. [3] published a report of livestock development in the Zambezi valley, also in 2016. It incorporates findings by Vernooij and Wilschut [8], available since the previous year at the Wageningen Centre for Development Innovation database. It is arguably the most detailed and updated Mozambican dairy value chain analysis to date and a good introductory reference for future researchers on the topic. They identified four processing plants (already described in Table 2) , described the daily production as 2,000 litres in Chimoio and 1,100 litres in Beira. They described some constraints for farmers such as limited market access, low productivity because of limited husbandry skills, lack of nutritious feed or suitable breeds for milk production, reproduction issues and disease, besides the fact that the most productive dairy cows are adapted to temperate climates [7,35]. Furthermore, Vernooij, et al. [3]:

- Identified the main actors in the value chain: the Government, a dairy cooperative in the city of Beira, non-governamental organizations (NGOs) and smallholders;

- Described the production in quantity and volume per province, some initiatives including

Manica Smallholder Dairy Development Program;

- Dairy cow feeding and reproduction;

- Analysis of strengths and weaknesses.

Mahomed and Nunes [6] published in 2018 an analysis of viability for the establishment of a new dairy factory in Mozambique. Their article summarizes Mahomed's dissertation [5] published in 2017. They focused on Maputo, Beira and Nampula because these are the country's major cities and the study was market-oriented. They provided unique insights about the consumer's point-of-view, discussing about perception on the price per liter, dairy purchase habits and patterns, milk substitutes, and a projection on dairy demand. Considering these variables, the market seems viable for the implantation a dairy manufacturer. This result subsidizes what the governor of Manica said [1], though Mahomed's studies were in different areas of the country. Moreover, their article is the only about the Mozambican dairy industry including butter among the products. This is a very important point because butter is arguably perceived as the most popular dairy product in Mozambique [52,65], eaten by virtually the entire population as part of the breakfast, accompanying bread or boiled cassava roots and black tea [65]. Most authors did not include butter possibly because most butter is imported from South Africa and many people consume margarine as a substitute because of its lower price, and margarines might have very little dairy among its ingredients [66].

Yet, value chain analysis so far mentioned condensed milk, but the local population consumes it frequently, uses it for baking and knows very well the manufacturers. The most widely known manufacturer is Protal, the country's major dairy company before the arrival of Parmalat [58]. The enterprise predates independence and remained active through all sociopolitical changes. It commenced in 1956 when the industrialist Jaime Cardoso sold his Hotel in Beira and set up a dairy 
import-export company in Lourenço Marques (now Maputo City). He imported condensed milk, competing directly with the Nestlé brand Cruz Azul. Later, his firm merged with Protal, founded in 1968 [49]. The company has approximately 70 workers, most engaged in production and packaging. Their main products are condensed milk under the brands "Protal" and "Blue Crown", and Belarosa processed cheese. This story conflicts with Zvomuya's [9] claims about Gouda Gold as the first cheese manufacturer, but maybe the author meant "first primary producer", as Protal imports its raw materials. The only research on Protal was published in two dissertations of chemical studies $[1,50]$ and a biography of Carlos Cardoso [58], a deceased influential journalist. The dissertations will be examined in the section 5.2 .

So far, the social and economics Mozambican dairy research seems to be increasingly intense as the sector also develops, especially the smallholders. Most research was associated with Manica Smallholder Dairy Development Program but new initiatives will possibly trigger further research. For instance, the papers published by Faftine [28] and Castel-Branco [4] were not really focused on the dairy industry and mentioned it as an example to illustrate their particular arguments towards concerns non-related to dairy, while latest studies $[6,8]$ were assessments of dairy value chain in the country. The article by Mahomed and da Silva Nunes [6] implied the intention to install a dairy factory in Mozambique.

\subsection{Natural and Applied Sciences}

Research on natural or applied sciences seemed frequently related to the social and economic counterparts, sometimes as a component of the others. It happened through synergies, such as cases in which companies and research institutions joined efforts to analyze dairy production but each organization acted according to its own expertise or interests. For instance, Eduardo Mondlane University (UEM) collaborated with other organizations such as University of Zimbabwe [51], Wageningen University and Research [3], Future Farming Systems Group and other institutions [54]. Even within UEM different faculties have collaborated, exploring different aspects of dairy production. Thus, there will be some references to the works described in the previous sections. The studies will be presented according to subjects rather than a chronological order for the sake of thematic coherence, starting by the biological studies and then covering the chemical analyses.

This section will cover first the study by dos Anjos, et al. [51] in 2014. They analyzed the potential of cassava plant to be integrated in dairy cattle diet as an affordable energy source, as this practice had been introduced in some tropical countries. Feeding trials using cassava hay showed a dry matter intake (DMI) of $3.2 \%$ of the body weight (BW) and digestibility of $71 \%$. Other benefits were low feeding cost if compared to maize-based feed, anthelmintic and therapeutic effect due to the presence of tannins. This study is related to the one by Chagunda, et al. [54] mentioned in the section 5.1 about how to improve the productivity in dairy farms. These authors mentioned many other examples supporting the use of cassava as a viable alternative to lower dairy production cost.

Ten years earlier, Achá, et al. [33] actually published the first major post-war scientific study on dairy farming. They screened calves 1241 for diarrhea, aiming to analyze the prevalence and etiology. The calves belonged to 8 farms throughout the country. The prevalence was low (5\%) but relatively high in two farms (13\% and $21 \%$ ). Among the calves with diarrhea, and $11 \%$ were positive to Campylobacter jejuni, 2\% for Salmonella spp. and 40\% to K99 adhesin, indicating the presence of enterotoxigenic Escherichia coli (ETEC). Some sources described a different pattern of prevalence $[67,68]$ at which ETEC is more frequent, followed by Salmonella spp. and less frequently C. jejuni and Clostridium perfringens. Achá, et al. [33] said the unusual abundance of Campylobacter might have been related to outbreaks in some farms. This seems to be a promising research direction. For instance, the authors could have searched for the true cause of the differences with other studies; they could have included other microorganisms or parasites, analyze the impact of disease on the farms' productivity or much more. However, this study apparently had no follow-up.

In 2013, Schutte [50] published another microbiological study as a masters dissertation the University of Stellenbosch, South Africa. The author's focus was on the microbial flora of traditionally fermented milks in Sub-Saharan Africa, including a drink called masse from 
Mozambique. Masse is a beverage prepared through spontaneous fermentation of raw milk. It has a sour taste and a considerably dense consistency, similar to yogurt. Schutte [50] detected Leuconostoc in $68 \%$ of the samples (average $2000 \mathrm{cfu} / \mathrm{ml}$ ). The author did not study the safety as the interest seemed turned to organoleptic properties. Masse and other African traditional fermented milks have more diversity in microorganisms when compared to commercial fermented milks, meaning that they possess very rich florae with potential to provide new properties to foods commercially available. This was a very innovative and necessary line research, though it is advanced for an industry still thriving to exist in Mozambique. Yet, as it is a local traditional drink, people already have the know-how to produce it. Furthermore, the country could gain some competitive advantage by legally protecting as traditional knowledge or under geographical indication through the Agreement on Trade-Related Aspects of Intellectual Property Rights (TRIPS) [69].

Finally, there are studies on dairy chemical properties, all licentiate dissertations from the Faculty of Sciences, Eduardo Mondlane University. The first was published by Rungo [48], who developed a set of protocols for experiments on chemical engineering. His dissertation catalogs major processes to analyze the quality of condensed milk, such as fat extraction and quantification of sucrose. This study did not contain any novelty because it was not meant to, but it is among the few scholarly documents mentioning Protal as a major dairy company in Maputo City. However, it was not merely focused on dairy production as the author interviewed and reviewed processes from several chemical industries. Zucula [49] was the only one who specifically studied condensed milk processing by Protal, providing the only Mozambican scholarly description published to date about dairy's full analytical process for quality control and assurance, including the chemical, microbiological and organoleptic components. Ouana [52] evaluated the quality of Tulip butter and two margarine brands (Rama and Flora), all imported but widely consumed locally. According to the author, the values were within the Codex Alimentarius limits for acidity, iodine, fat, volatile substances and impurities insoluble in ether. A unique aspect of this study is the attention to butter and even margarine, perhaps the most important but "underrated" dairy products in Mozambican academic circles, possibly because they bear little resemblance to the raw material. Curiously, yogurt also seems underrated.

\section{Conclusions and recommendations}

It was an exaggeration to say that there is virtually no dairy industry in Mozambique. Castel-Branco gave perhaps the most accurate description by saying that it is an emerging agricultural industry, lacking some elements to be fully established and using mostly local input. There is a market and value chain, modestly defined. What the Mozambican dairy industry needs is proper leadership and collaboration to face numerous challenges including "almost unfair" foreign competitors. One successful example was the Manica Smallholder Dairy Development Program. It would not have been possible without the investment for sure, but part of its success was certainly due to a well-coordinated plan of activities and allocation of resources. Furthermore, the government should issue and enforce policies encouraging large companies to prioritize the milk locally produced over imports, and build infrastructures to collect milk from the smallholder dairy farmers.

Regarding dairy research, it is emerging likewise. Scholars might be facing difficulties getting funding because priorities are turned toward cash crops and other food industries more developed such as fisheries or poultry. Yet, there seems to be increasing production interest on dairy in Mozambique, together with the incentives for entrepreneurship and a larger number of research facilities, opportunities and experts. Hopefully, each case of success will spread optimism among actual and potential stakeholders and maybe the country will be able to better deal with the external competition.

There are also different research directions, all promising. Perhaps the most important is not to stop any project in the middle or stimulate follow-ups. The academic departments or research centers should design projects with mid or long term impact, and also collaborate more by creating multidisciplinary synergies able to study the dairy production from different perspectives. There are 
a few industry analyses and studies on applied sciences. Academia and research centers should encourage students, young researchers and entrepreneurs to pursue dairy industry quests and bring solutions to each challenge. For instance, it would be advantageous if the country could explore the potential of traditional dairy products and start an all-new industry, gaining competitive advantage.

Above all, there are probably various documents like the ones in the Library of the Food and Agricultural Organization, existing only in the physical format. This is probably because they were issued prior to the expansion of electronic resources such as the worldwide web. These documents would be an asset to researchers if available online. Even if such documents seem outdated they can bring unparalleled insights, able to provide a more accurate picture about the dairy production landscape in Mozambique.

Funding: This research received no external funding.

Conflicts of Interest: The author declares no conflict of interest.

\section{References}

1. Zvomuya, F. Gouda goes for gold: Processing. Dairy Mail Africa: Publication for the Dairy Industry in Africa 2009, 4, 19-23.

2. Johnson, N.; Njuki, J.; Waithanji, E.; Nhambeto, M.; Rogers, M.; Kruger, E.H. The importance of gender in a "gender blind" asset transfer program: Lessons from dairy development in mozambique. In Gender, agriculture, and assets: Learning from eight agricultural development interventions in africa and south asia, Quisumbing, A.; Meinzen-Dick, R.; Njuki, J.; Johnson, N., Eds. International Food Policy Research Institute: Washington, DC, 2013; pp 25-28.

3. Vernooij, A.; dos Anjos, M.; van Mierlo, J. Livestock development in the zambezi valley, mozambique: Poultry, dairy and beef production; CDI-16-027; Wageningen UR (University and Research) Centre for Development Innovation: Wageningen, 2016; pp 32-42.

4. Castel-Branco, C.N. Indústria e industrialização em moçambique: Análise da situação actual e linhas estratégicas de desenvolvimento. I Quaderni della Cooperazione Italiana 2003, 3, 2003.

5. Mahomed, N.A. Plano de negócios: Estudo de viabilidade para a abertura de uma fábrica de laticínios em moçambique. Universidade Federal de Santa Catarina, Florianópolis, 2017.

6. Mahomed, N.A.; da Silva Nunes, R. Análise de viabilidade do mercado: Implantação de uma fábrica de laticínios em moçambique. Revista Gestão em Análise 2018, 7, 85-105.

7. Alberro, M. Comparative performance of holstein-friesian, dutch-friesian and friesian $\times$ africander heifers in the coastal belt of mozambique. Animal Science 1980, 31, 43-49.

8. Vernooij, A.G.; Wilschut, S. The dairy sector of mozambique; Centre for Development Innovation, Wageningen UR: Wageningen, 2015.
9. Central
Intelligence
Agency
(CIA).
Mozambique.

https://www.cia.gov/library/publications/the-world-factbook/geos/mz.html (12 June 2013),

10. Instituto Nacional de Tecnologias de Informação e Comunicação (INTIC). Informação geral sobre moçambique. http://www.portaldogoverno.gov.mz/Mozambique (13 June 2013),

11. Encyclopædia Britannica.

Mozambique. http://www.britannica.com/EBchecked/topic/395363/Mozambique (8 August 2013),
12.
mozambique.

Geographic Guide.
http://www.geographicguide.com/africa-maps/mozambique.htm (9 August 2018),

Geographic Guide.
http://www.geographicguide.com/africa-maps/mozambique.htm (9 August 2018),

Geographic Guide.
http://www.geographicguide.com/africa-maps/mozambique.htm (9 August 2018),

13. World Bank. Mozambique at a glance. In Development Economics, LDB database: Washington DC, United States, 2013. 
463 14. United Nations Children's Fund (UNICEF). Mozambique at a glance.

464 http://www.unicef.org/mozambique/overview_11146.html

465 15. Canadian International Development Agency (CIDA). Mozambique: Facts at a glance. 466 http://www.acdi-cida.gc.ca/acdi-cida/ACDI-CIDA.nsf/En/JUD-22211545-LVP (13 June 2013),

467 16. Bertelsmann Stiftung. Bti 2012 - mozambique country report; Bertelsmann Stiftung: Gütersloh, 2012.

468 17. Reserve of Australia (RBA). Exchange rates. 469 http://www.rba.gov.au/statistics/frequency/exchange-rates.html (13 June 2013),

470 18. The Economic and Policy Analysis Unit (EPAU). Mozambique quick facts: Economic and policy 471 analysis unit. UNDP Mozambique, Ed. The Economic and Policy Analysis Unit (EPAU), UNDP 472 Mozambique: Maputo, 2012.

473 19. United States Agency for International Development (USAID). An assessment of mozambique's $474 \quad$ intellectual property system; United States Agency for International Development (USAID): 2009.

20. McMillan, M.; Rodrik, D.; Welch, K.H. When economic reform goes wrong: Cashews in mozambique; National Bureau of Economic Research: Cambridge, 2002.

21. World Bank. Mozambique agricultural development strategy: Stimulating smallholder agricultural growth; 32416-MZ; World Bank: Washington DC, United States, 2006.

22. Große-Rüschkamp, A.; Seelige, K. Análise da cadeia de valor do caju em moçambique. Deutsche Gesellschaft für Internationale Zusammenarbeit (GIZ) GmbH: Maputo, 2010.

23. José, A.C. Autoridades ardilosas e democracia em moçambique. O Cabo dos Trabalhos. Revista electrónica dos Programas de Mestrado e Doutoramento do CES/FEUC/FLUC 2005, 1.

24. Kates, R.W.; Parris, T.M.; Leiserowitz, A.A. What is sustainable development? Goals, indicators, values, and practice. Environment 2005, 47, 8-21.

25. Raikes, P. Food policy and production in mozambique since independence. Review of African Political Economy 1984, 11, 95-107.

26. Mosca, J. Agricultura de moçambique pós-independência: Da experiência socialista à recuperação do modelo colonial. 2008.

27. Vieira, S.P. Crescimento económico, desenvolvimento humano e pobreza: Análise da situação em moçambique. 2005.

29. Castel-Branco, C.N. Parp 2011-2014: Contradições, tensões e dilemas. Desafios para Moçambique 2012, 105-115.

497 30. Slabbert, K. Parmalat-not just about the bottom line: Processing. Dairy Mail Africa: Publication for the Dairy Industry in Africa 2008, 3, 23-25.

499 31. Cambaza, E.; Koseki, S.; Kawamura, S. Aflatoxins in mozambique: Impact and potential for intervention. Agriculture 2018, 8, 100.

501 32. Pereira Martinho, J. Some aspects of the livestock problem in mozambique. Lourenço Marques: Tipografia $502 \quad$ Spanos.: 1956; p 108 pp.

$503 \quad$ 33. Achá, S.J.; Kuhn, I.; Jonsson, P.; Mbazima, G.; Katouli, M.; Mollby, R. Studies on calf diarrhoea in 504 mozambique: Prevalence of bacterial pathogens. Acta Vet Scand 2004, 45, 27-36. 
505 34. Food and Agriculture Organization of the United Nations (FAO). Welcome to fao library \& archives. 506 http://www.fao.org/library (1 August 2018),

507 35. Alberro, M. A friesian dairy herd in the coastal belt of mozambique. Management, feeding and 508 behaviour. World Animal Review 1981.

509 36. Diaz, J. In [abortion and dead born in the dairy industry of maputo, mozambique].[spanish], 10. international 510 congress on animal reproduction and artificial insemination. University of Illinois at

37. Rocha, A.; Diaz, J. In [artificial insemination of dairy cattle in mozambique].[spanish], 10. international congress on animal reproduction and artificial insemination. University of Illinois at Urbana-Champaign, Illinois (USA). 10-14 Jun 1984., 1984.

Alinder, S.; Ingevall, A. Soil survey and irrigation scheme design for a dairy farm in southern mozambique. Arbetsrapport-Sveriges Lantbruksuniversitet, U-landsavdelningen (Sweden) 1985. de Vries, H. In [a trial using rice straw in a small dairy unit].[portuguese], Seminario de Producao Animal. Maputo (Mozambique). 2-7 Dec 1985., 1986.

Diaz, J. In Some ideas on dairy cattle production in mozambique, Seminario de Producao Animal, Maputo (Mozambique), 2-7 Dec 1985, 1986. 61-91. Coelho, J.P.B. State resettlement policies in post-colonial rural mozambique: The impact of the

44. Davis, K.E.; Ekboir, J.; Spielman, D.J. Strengthening agricultural education and training in sub-saharan africa from an innovation systems perspective: A case study of mozambique. Journal of agricultural education and extension 2008, 14, 35-51.

46. Vala, S.C. In "A riqueza está no campo": Economia rural, financiamento aos empreendedores e fortalecimento institucional em moçambique, "A Riqueza Está no Campo": Economia Rural, Financiamento aos Empreendedores e Fortalecimento Institucional em Moçambique, 19 September 2007, Maputo, Mozambique, 2007; Conference Paper: Maputo, Mozambique, p 43.

Weimer, B. Para uma estratégia de descentralização em moçambique:'Mantendo a falta de clareza?': consequências para a governação em moçambique. B. Weimer, Moçambique: Descentralizar $O$ Centralismo. Economia Política, Recursos e Resultados 2012, 168-194.

Rungo, M.J. Proposta de uma ficha prática de química analítica para o curso de engenharia química, relacionada com actividades industriais. Universidade Eduardo Mondlane, Maputo, 2011.

Zucula, Z.A. Estudo da dependência da qualidade do leite condensado coroa azul produzido pela fábrica protal-produtos alimentares com o tempo e a temperatura de conservação. Universidade Eduardo Mondlane, Maputo, Mozambique, 2012. 
$54750 . \quad$ Schutte, L.M. Isolation and identification of the microbial consortium present in fermented milks from sub-saharan africa. Stellenbosch: Stellenbosch University, 2013.

51. dos Anjos, F.R.; Tivana, L.; da Cruz, F.J.; Kagande, S.M. Cassava (manihot esculenta crantz): An

52. Ouana, M.A. Controlo de qualidade de manteiga (tulip) e margarinas (rama e flora) comercializadas e consumidas em maputo. 2014.

53. Johnson, N.; Njuki, J.; Waithanji, E.; Nhambeto, M.; Rogers, M.; Kruger, E.H. The gendered impacts of agricultural asset transfer projects: Lessons from the manica smallholder dairy development program. Gender, Technology and Development 2015, 19, 145-180.

54. Chagunda, M.G.G.; Mwangwela, A.; Mumba, C.; Dos Anjos, F.; Kawonga, B.S.; Hopkins, R.; Chiwona-Kartun, L. Assessing and managing intensification in smallholder dairy systems for food and nutrition security in sub-saharan africa. Regional environmental change 2016, 16, 2257-2267.

55. Benfica, R.; Arlindo, P.; Weber, M.T.; Tschirley, D.L. Características dos agregados familiares rurais 56. Food and Agriculture Organization of the United Nations (FAO). Milk, whole fresh cow. In UN data, 7 nas zonas afectadas pelas cheias do ano 2000 no centro e sul de moçambique. 2000.

May 2018 ed.; United Nations Statistics Division: Rome, Italy, 2018.

57. Muriuki, H.; Thorpe, W. In Smallholder dairy production and marketing in eastern and southern africa: Regional synthesis, Smallholder dairy production and marketing-opportunities and constraints, Anand, India, 13-16 March 2001, 2001; Rangnekar, D.; Thorpe, W., Eds. National Dairy Development Board: Anand, India, pp 185-200.

8. Fauvet, P.; Mosse, M. Carlos cardoso: Telling the truth in mozambique. Juta and Company Ltd: 2003.

59. Horne, B. The maputo corridor is breathing, but needs some oxygen: Zooming in. Transport World Africa 2006, 4, 6-11.

60. Department of Agriculture, F.a.F. A profile of the south african dairy market value chain; Department of Agriculture, Forestry and Fisheries, South Africa (DAFF): Arcadia, South Africa, 2012.

61. Hassan, S.; Simione, F. Exchange rate determination under monetary policy rules in a financially underdeveloped economy: A simple model and application to mozambique. Journal of International Development 2013, 25, 502-519.

62. Brännäsa, K.; Machavaab, A. Time series modelling of daily metical/rand exchange rate returns, 1996-2014; Umeå University, Department of Economics: 2015.

63. Land O' Lakes. Mozambique fact sheet. In United States Department of Agriculture (USDA), Development, L.O.L.I., Ed. Land O' Lakes International Development: Shoreview, United States, 2016.

64. Land O' Lakes. Researched the role of gender in household decisions. https://www.landolakes.org/where-we-work/africa/mozambique/mozambique-gender,-agriculture-a nd-assets-projects (8 August 2018),

65. Rose, D.; Meershoek, S.; Ismael, C.; McEwan, M. Evaluation of a rapid field tool for assessing household diet quality in mozambique. Food Nutr Bull 2002, 23, 181-189.

66. Merriam-Webster. Margarine. https://www.merriam-webster.com/dictionary/margarine (9 August 2018),

67. Muktar, Y.; Mamo, G.; Tesfaye, B.; Belina, D. A review on major bacterial causes of calf diarrhea and its diagnostic method. Journal of Veterinary Medicine and Animal Health 2015, 7, 173-185. 
588 68. Olaogun, S.C.; Jeremiah, O.T.; Jubril, A.J.; Adewuyi, O.O. Calf diarrhea: Epidemiological prevalence and bacterial load in oyo and ogun states, nigeria. Alexandria Journal of Veterinary Sciences 2016, 51, 90-96.

591 69. Helfer, L.R. Regime shifting: The trips agreement and new dynamics of international intellectual property lawmaking. Yale J. Int'l L. 2004, 29, 1. 